\title{
Role of small-plankton communities in the diet of two Antarctic octocorals (Primnoisis antarctica and Primnoella sp.)
}

\author{
Covadonga Orejas $^{1, *}$, Josep-Maria Gili ${ }^{2}$, Wolf Arntz ${ }^{1}$
}

\begin{abstract}
${ }^{1}$ Alfred Wegener Institute for Polar and Marine Research, Columbusstrasse, 27568 Bremerhaven, Germany ${ }^{2}$ Institut de Ciències del Mar (CMIMA-CSIC), Passeig Marítim de la Barceloneta 37-49, 08003 Barcelona, Spain
\end{abstract}

\begin{abstract}
The diet composition of 2 Antarctic octocorals, Primnoisis antarctica and Primnoella sp., from the shelf of the eastern Weddell Sea (Antarctica) is studied here for the first time. Although mesozooplankton is very scarce in the diet of these organisms, it seems to be important because of its high carbon content. Feeding experiments showed that components of the seston, including the finer fraction of suspended organic matter (ciliates, dinoflagellates and phytoplankton), are also an important part of the octocoral diet. In P. antarctica, the diatom Fragillariopsis spp. accounted for $77 \%$ of the total number of cells captured, followed by dinoflagellates (20\%), Nitzschia spp. (2\%) and ciliates $(1 \%)$. In Primnoella sp., dinoflagellates were consumed preferentially $(92 \%)$, followed by ciliates $(6 \%)$ and centric diatoms $(2 \%)$. Biomass consumed, however, was low $\left(1.11 \times 10^{-5} \mathrm{mg} \mathrm{C}\right.$ polyp $^{-1} \mathrm{~d}^{-1}$ for $P$. antarctica and $1.34 \times 10^{-4} \mathrm{mg} \mathrm{C}$ polyp ${ }^{-1} \mathrm{~d}^{-1}$ for Primnoella sp.). In P. antarctica, small plankton food covers approximately $49 \%$ of the daily energy demand. The ability of these suspension feeders to capture small cells at lower concentrations may allow them to remain seasonally active for considerably longer periods than previously thought.
\end{abstract}

KEY WORDS: Feeding ecology · Suspension feeders · Antarctic gorgonians · Small-plankton communities

\section{INTRODUCTION}

The seston, the total particulate matter suspended in the water column, consists of an enormous variety of substances that includes detrital particulate organic matter and planktonic animals and plants, dynamically linked by the microbial food web (Azam et al. 1983). Despite its variety and ubiquity, the seston represents a highly dilute food source (Riisgård \& Larsen 2001) to potential consumers, such as sessile suspension feeders that typically dominate benthic communities (Officer et al. 1982, Gili \& Coma 1998). These organisms are able to capture substantial amounts of seston and planktonic prey, and the grazing pressure on the water column planktonic communities by benthic macro-invertebrates appears to be much greater than previously thought (e.g. Pile et al. 1996, Gili \& Coma 1998, Orejas et al. 2001).

*Email: orejas@zmt.uni-bremen.de
Many anthozoans, such as corals, zoantharians, alcyonaceans and actinians, are among the more conspicuous components in littoral benthic communities in temperate and tropical areas (e.g. True 1970, Loya 1972). In situ prey capture rates are available for a small number of species (e.g. Lewis 1982, Coma et al. 1994, Sebens et al. 1996). These studies have mainly focused on zooplankton as principal prey items. Gorgonians have rarely been shown to capture zooplankton (e.g. Lasker et al. 1983). Alternative food sources, such as suspended particulate matter (Lasker 1981), mucus produced by corals (Coffroth 1984), dissolved organic matter (Murdock 1978) and microplankton (Ribes et al. 1999a), have been proposed. In fact, significant capture of zooplankton prey occurring in situ has only been shown in the Mediterranean species Paramuricea clavata Risso (Coma et al. 1994). Even in this species, 
the capture of zooplankton only accounted for about $50 \%$ of its energy requirements. The remaining demand must be covered by small seston (Ribes et al. 1999a). Recent studies have suggested that the communities of small plankton (mainly phytoplankton) play an important role in the diet of various benthic anthozoans and other suspension feeders in temperate and boreal latitudes (e.g. Ribes et al. 1998a, 1999b, Riisgård et al. 1998), tropical areas (Fabricius et al. 1995, Yahel et al. 1998), and also in the Antarctic (Kowalke 2000, Orejas et al. 2001). However, the study of gastrovascular contents of gorgonians in Antarctic waters (Alvà et al. 1997) revealed a very low number of zooplankton prey items. This would seem to be a paradox taking into account that summer is the period in the Antarctic when higher primary production rates and higher zooplankton densities occur. Additionally, the high reproduction rates of octocorals in Antarctic waters are comparable to those from other latitudes (Orejas et al. 2002), indicating that other planktonic components must be consumed by these organisms in order to meet their energy demands.

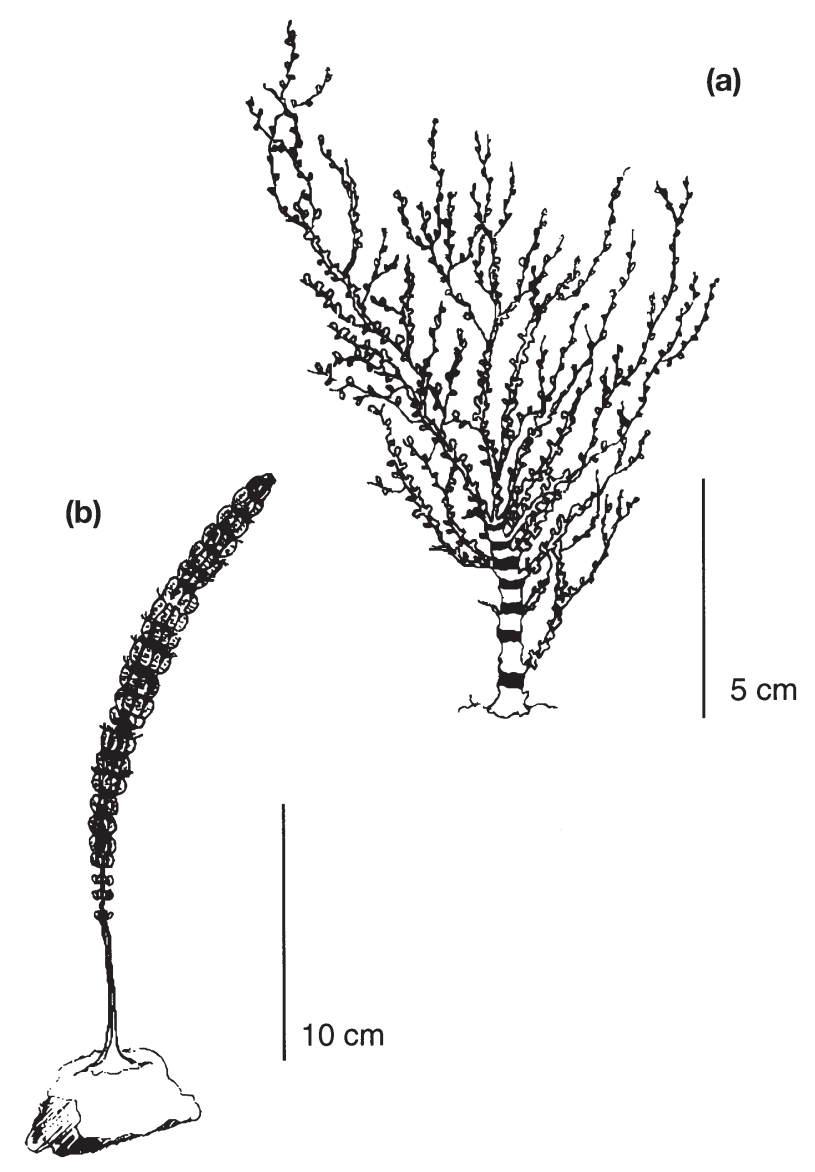

Fig. 1. Studied species. (a) Primnoisis antarctica, (b) Primnoella sp.
In recent years, ecological work on Antarctic suspension feeders has increased notably, for instance, on bivalves (e.g. Davenport 1997, Albertelli et al. 1998), sponges (e.g. Starmans et al. 1999, Kowalke 2000), ascidians (e.g. Sahade et al. 1998, Kowalke 1999) and bryozoans (e.g. Sanderson et al. 1994, Barnes \& Clarke 1994). Some studies on boreal sponges are also available (e.g. Pile et al. 1996, Riisgård et al. 1998). However, studies on passive suspension feeders in polar regions are still scarce, even though they represent a conspicuous group in benthic Antarctic shelf communities (e.g. Arntz et al. 1994, Gutt \& Starmans 1998). According to Starmans et al. (1999), anthozoans are the third dominant taxon in the shelf communities of the Weddell Sea and account for $10 \%$ of individuals.

It has long been assumed that Antarctic ecosystems experience an extended period of biological inactivity because of the long periods of ice cover (Gruzov 1977). However, recent studies on Antarctic shallow waters suggested only a brief period of feeding inactivity in some Antarctic benthic suspension feeders (Barnes \& Clarke 1995). This is related to the finding at littoral sites that in winter nanoplankton chlorophyll a (chl a) exceeds that of the microplankton for approximately 3 mo (Clarke \& Leakey 1996).

Pico- (cells $<2 \mu \mathrm{m}$ ) and nanoplankton (cells 2 to $20 \mu \mathrm{m})$ dominate many planktonic communities in terms of production (e.g. Platt et al. 1983, Stoeckner \& Antia 1986, Burkill et al. 1993). The plankton of the Southern Ocean is dominated by nanoflagellates and small pennate diatoms (e.g. Sakshaug \& Holm-Hansen 1984, Nöthig et al. 1991, Scharek \& Nöthig 1995). These organisms are rare during winter but bloom during spring. In contrast, heterotrophic nanoflagellates, dinoflagellates and ciliates are present practically all year round (Hewes et al. 1985). This 'split' planktonic system might provide a key to the understanding of the ecology of benthic suspension feeding organisms.

In this study, we examine the role of small plankton in the diet of 2 Antarctic gorgonians. We focused on 3 main questions: (1) which particles are captured by the 2 species and in what proportions; (2) what is their diet in comparison with that of other suspension feeders around the world; and (3) how can this diet help to explain the role of suspension feeders in Antarctic ecosystems and, in particular, the lack of an extended inactive period in benthic Antarctic communities.

\section{MATERIALS AND METHODS}

Description of the species and sampling. Primnoisis antarctica (Studer, 1879) (Isididae, Octocorallia) is a branched gorgonian with arborescent growth form (Fig. 1a). Specimens were collected from soft substrata 
in a depth range between 200 and $500 \mathrm{~m}$. The second species, Primnoella sp. (Primnoidae, Octocorallia) (Fig. 1b), is also common but it remains to be determined because of the extreme variability of the genus (P. J. López-González pers. comm.). It has a flagelliform, unbranched shape, with polyps arranged in whorls. This species lives attached to stony substrata and occurs mainly in shallow areas (ca. 60 to $100 \mathrm{~m}$ depth).

Sampling was carried out on board RV 'Polarstern' during the EASIZ II cruise (ANT XV/3, January to March 1998) in the Kapp Norvegia area (eastern Weddell Sea, approximately $71^{\circ} 5^{\prime} \mathrm{S}, 13^{\circ} 01^{\prime} \mathrm{E}$ ) at depths of 60 to $500 \mathrm{~m}$ (Fig. 2). Expedition details are given in Arntz \& Gutt (1999). Specimens were sampled with a large TV grab of $1.82 \mathrm{~m}^{2}$ area and immediately transferred to sea water aquaria maintained at Southern Ocean temperature $\left(-1\right.$ to $\left.0.5^{\circ} \mathrm{C}\right)$. The sampled area was characterised by Voß (1988), who described the presence of sandy bottoms but also sponge spicule mats, bryozoan debris and a few stones. High species richness, diversity and evenness are also characteristic of the Kapp Norvegia area (Galéron et al. 1992).

Gastrovascular contents. To determine the role of zooplankton prey in the diet of both species, polyp gastrovascular contents were analysed; 195 polyps from 13 colonies of Primnoisis antarctica and 200 polyps from 8 colonies of Primnoella sp. were dissected under a binocular and a light microscope. The prey items were identified, where feasible to taxa, and their sizes measured. Calculation of biomass values for the various groups was done using conversion values from various sources (Edler 1979, Coma et al. 1995, S. Schiel unpubl. data).

Feeding experiments. The role of small plankton in the diet of Primnoisis antarctica and Primnoella sp. was also evaluated from feeding experiments. A modified form of the incubator developed by the Institut de Ciències del Mar (Ribes et al. 1998a, 2000) was used to study the diet of benthic suspension feeders. The incubator consists of a chamber of $5 \mathrm{l}$ volume in which the colony is placed, and an empty control chamber (Fig. 3). Each closed chamber was connected to a pump that re-circulated the seawater at a renewal rate of $3.31 \mathrm{~min}^{-1}$. The experiments were carried out at a constant flow speed in order to avoid particle sedimentation. Increasing flow in the incubation chamber may accelerate the particle capture by gorgonians but not the final capture rate due to the long incubation time.

Water was collected as close to the seafloor as possible by means of a CTD equipped with a rosette. Temperature and salinity were simultaneously measured. The chambers and all required material and instrumentation were held in a refrigerated experimental room to maintain environmental temperature. Co-

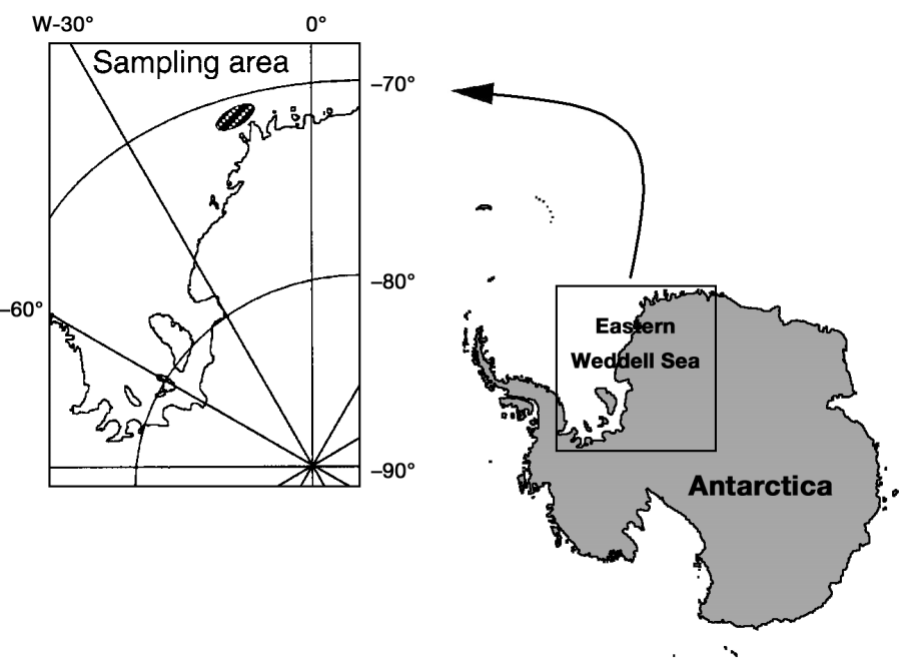

Fig. 2. Sampling area in the high Antarctic Weddell Sea

lonies were held in the cooled aquarium until the incubation experiments were carried out. Immediately prior to the experiments, animals $(6$ specimens were used for each species) were placed in the experimental chamber and were allowed to fully expand. After this period of acclimation (3-4 h), the incubation chambers were closed and initial water samples of $2000 \mathrm{ml}$ were taken from both chambers. A second set of water samples was collected $6 \mathrm{~h}$ later. The fact that the experimental design considered only an initial and a final sample could generate some uncertainty in the final results. The reduced prey concentrations in the water samples forced us to take large samples for the different analyses. Due to the limited capacity of the experimental chambers and the high volume of the water samples, it was not possible to take samples in different sampling intervals, although this would have been

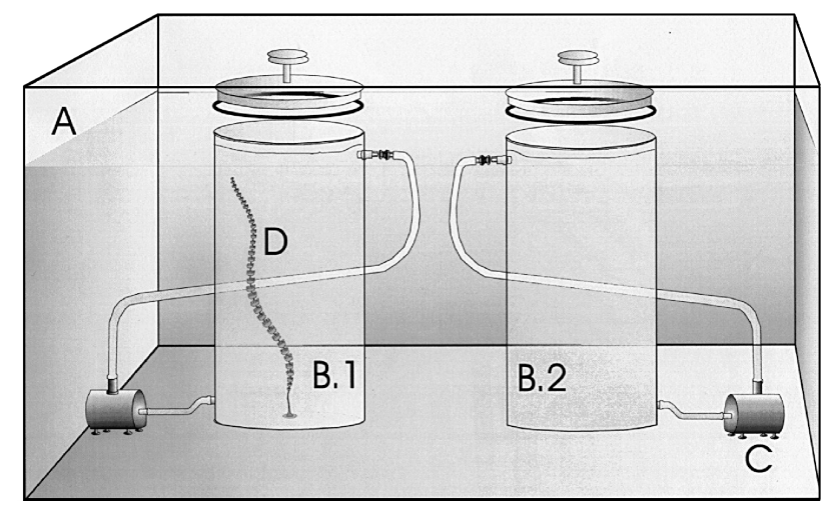

Fig. 3. Experimental device for the feeding experiments. A: Aquarium container, B.1: experimental chamber, B.2: control chamber, C: pump, D: specimen 
ideal in order to check the half-life of different prey organisms and particle size.

Capture rates were calculated using the variation in the concentration levels of bacteria, nanoflagellates, ciliates, dinoflagellates, diatoms, total particulate organic carbon (POC) and dissolved organic carbon (DOC) in the water samples. Corrections were made for the net growth rate of bacteria, nanoflagellates, ciliates, dinoflagellates and diatoms, and for the net increasing rates of POC and DOC during the experiment as revealed by the control chamber. Depletion rates were calculated by assuming exponential growth and clearance of prey (Saiz 1993). Thus, the prey growth rate $k$ is computed $\left(\mathrm{h}^{-1}\right)$ as:

$$
k=\ln \left(C_{1} / C_{0}\right) / t_{1}-t_{0}
$$

where $C_{0}$ and $C_{1}$ are the prey concentrations in the chamber at the initial time $t_{0}$ and the final time $t_{1}$. The clearance rate $C R$ (volume swept clear biomass ${ }^{-1}$ time $^{-1}$ ) is calculated as:

$$
C R=V g / b
$$

where $V$ is the volume of the chamber, $b$ is the organisms biomass and $g$ is the grazing coefficient $\left(\mathrm{h}^{-1}\right)$, which is computed as:

$$
g=k_{c}-k_{e}
$$

where $k_{c}$ is the prey growth rate in the control chamber and $k_{e}$ is the apparent growth in the chamber with organisms. Finally, the ingestion rate $I$ (prey ingested biomass ${ }^{-1}$ time $^{-1}$ ) is:

$$
I=C R C
$$

where $C$ is the average prey concentration, calculated using the initial and final values of prey concentration during the experiment.

To quantify heterotrophic bacteria, water samples were stored for flow cytometry by standard methods (Gasol \& del Giorgio 2000). For quantification and measurement of nanoplankton (nanoflagellates), water samples were stained with DAPI; counting and measurement was done by epifluorescence microscopy (Porter \& Feig 1980). To quantify, measure and identify ciliates, dinoflagellates and diatoms, water samples were stored in acid Lugol (Utermöhl 1931, 1958) for subsequent microscopy.

Cell biovolume was calculated from length and width by approximation to the nearest regular geometric volume. Carbon content of heterotrophic bacteria was estimated from literature conversion factors (Fry 1988). For pico- and nanoplankton and for the different diatom groups, the method described in Edler (1979) was followed. Nutrients $\left(\mathrm{NO}_{2}, \mathrm{NO}_{3}, \mathrm{Si}\right.$ and $\left.\mathrm{PO}_{4}\right)$ in the water samples were measured using a Technikon autoanalyzer II system following standard methods
(Grasshoff 1976). Carbon content was measured using a Leco CN 2000 analyzer. Water samples for these analyses were taken close to the bottom, between 200 and $400 \mathrm{~m}$ depth, in the same areas where the specimens for the experiments were collected. Initial concentrations of plankton groups as well as POC and DOC in the experiments were also taken as environmental concentrations.

To calculate the biomass of the Primnoisis antarctica and Primnoella sp. colonies used in the experiments, specimens were rinsed with water to remove salt and associated macrofauna, and dry mass was determined after drying at $90^{\circ} \mathrm{C}$ for $24 \mathrm{~h}$. To determine ash-free dry mass (AFDM), the tissue and axis of the colonies were separated, and combusted separately at $450^{\circ} \mathrm{C}$ for $5 \mathrm{~h}$.

Depletion rates for the different potential prey items were calculated by assuming exponential growth and clearance of prey as described in Ribes et al. (1998b). Because the data were not normally distributed, a nonparametric test (Wilcoxon test) (Sokal \& Rohlf 1995) was used to identify possible differences between prey net growth rate, and POC, DOC and nutrients net increment rate in the experimental and control chamber.

Ingestion rates were estimated from the clearance rates calculated from the feeding experiments and the mean prey concentration value for each prey type during the experiment (Ribes et al. 1999b). Ingestion was expressed in terms of number of cells colony ${ }^{-1}$ time $^{-1}$ and in terms of carbon as a proportion of organic carbon weight of tissue time ${ }^{-1}$. All results are expressed as mean $\pm \mathrm{SD}$.

\section{RESULTS}

\section{Feeding on zooplankton}

A small number of zooplankton prey was found in the 195 analysed polyps of Primnoisis antarctica (Table 1). The maximal number of prey items per colony was 4, including 3 copepod nauplii and 1 tintinnid. Primnoella sp. did not contain any zooplankton prey in the dissected polyps. These results agree with the observations of Alvà et al. (1997) who also dissected polyps of different Antarctic gorgonian species, finding scarce zooplankton prey in their gastrovascular cavities.

It is difficult to estimate the contribution of zooplankton in the diet of Primnoisis antarctica without additional information about diel zooplankton capture rate. However, looking at the high carbon content of zooplankton prey items (Table 1), it is clear that they play a more important role in the diet of this species in terms of mass than is indicated by their low number. 


\section{Feeding on small-planktonic communities}

Net growth rates were calculated for each plankton taxon (excluding zooplankton bigger than $100 \mu \mathrm{m}$ ) and for POC and DOC in both the control and experimental chambers (Fig. 4). Net growth rates of ciliates and dinoflagellates, followed by Nitzschia spp., Fragillariopsis spp. and centric diatoms were generally lower in the experimental than in the control chamber. The concentrations of bacteria, nanoflagellates and POC increased in both chambers, but to a greater extent in the experimental one. In contrast, DOC showed a general decrease in concentration, being higher in the experimental chamber for Primnoisis antarctica and in the control chamber for Primnoella sp. Average prey concentrations (cells $\mathrm{l}^{-1}$ ) of ciliates, dinoflagellates and diatoms in the environment and during the experiments are shown in Table 2.

The Wilcoxon test applied to the results for Primnoisis antarctica detected statistically significant differences in the net growth rate $(\mathrm{p}<0.05)$ for Fragillariopsis spp. and for nanoflagellates. For Primnoella sp., statistically significant differences in the net growth rate $(p<0.05)$ were detected for ciliates, dinoflagellates and for DOC.

In our experiments, neither species appeared to graze on analysed organisms $<5 \mu \mathrm{m}$. Ingestion rates for
Table 1. Number and type of zooplankton prey items found in the gastrovascular cavities of Primnoisis antarctica, and carbon content of each prey item (expressed in $\mathrm{mgC}$ ). Sources for conversion to mgC: Edler (1979) and S. Schiel (pers. comm.)

\begin{tabular}{|lcccc|}
\hline Colony & $\begin{array}{c}\text { No. of dis- } \\
\text { sected polyps }\end{array}$ & $\begin{array}{c}\text { Prey } \\
\text { no. }\end{array}$ & $\begin{array}{c}\text { Prey } \\
\text { type }\end{array}$ & $\begin{array}{c}\text { mg C per } \\
\text { prey item }\end{array}$ \\
\hline 1 & 15 & 0 & - & - \\
2 & 15 & 0 & - & - \\
3 & 15 & 1 & Tinntinid & $\sim 3.2 \times 10^{-3}$ \\
4 & 15 & 0 & - & - \\
5 & 15 & 2 & Nauplii & $\sim 7.5 \times 10^{-3}$ \\
& & & Tinntinid & $\sim 3.2 \times 10^{-3}$ \\
6 & 15 & 0 & - & - \\
7 & 15 & 0 & - & - \\
8 & 15 & 1 & Invert. larvae & $\sim 7.2 \times 10^{-5}$ \\
9 & 15 & 0 & - & - \\
10 & 15 & 0 & - & - \\
11 & 15 & 4 & Nauplii $(3)$ & $\sim 7.5-18.0 \times 10^{-3}$ \\
& & & Tintinnid & $\sim 3.2 \times 10^{-3}$ \\
12 & 15 & 1 & Nauplius & $\sim 11.0 \times 10^{-3}$ \\
13 & 15 & 0 & - & - \\
\hline
\end{tabular}

both species are summarised in Table 3. The highest ingestion rate (cells polyp ${ }^{-1} \mathrm{~d}^{-1}$ ) in Primnoisis antarctica was for Fragillariopsis spp. followed by dinoflagellates, Nitzschia spp. and ciliates. In Primnoella sp., the

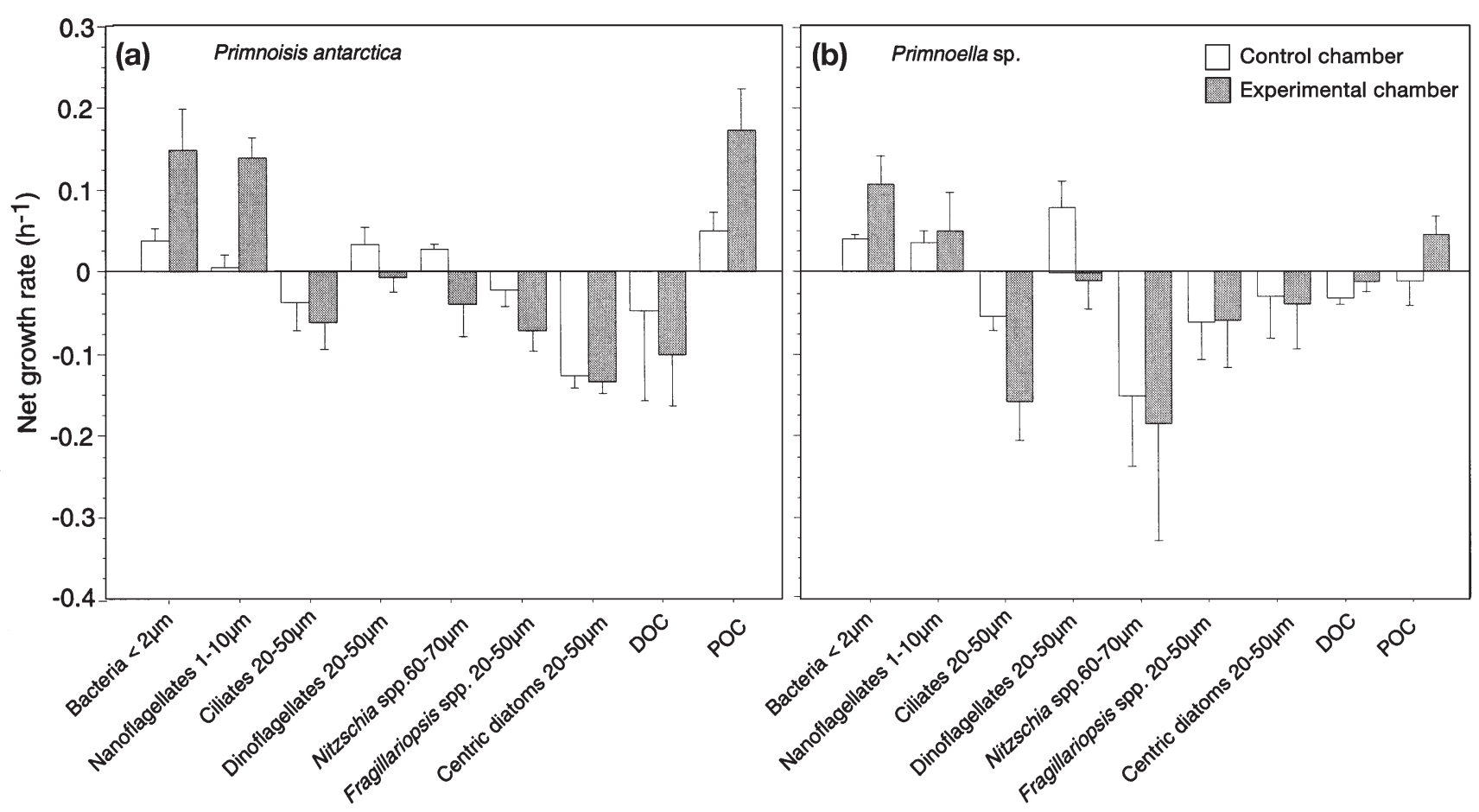

Fig. 4. Net growth and increasing rates $\left(\mathrm{h}^{-1}\right)$ (mean $\pm \mathrm{SD}$ ) of each plankton group, particulate (POC) and dissolved (DOC) organic carbon in the control (white bars) and experimental (shaded bars) chambers for (a) Primnoisis antarctica and (b) Primnoella sp. Size range of each plankton group is indicated. Bars indicate SD 
Table 2. Small-plankton group concentrations (C); initial values (control) and mean values of experimental chambers containing Primnoisis antarctica and Primnoella sp. Control concentrations used as environmental concentrations for the different groups and components of the fine fraction of seston. DOC: dissolved organic carbon. POC: particulate organic carbon

\begin{tabular}{|c|c|c|c|c|}
\hline \multirow{2}{*}{$\begin{array}{l}\text { Small-plankton } \\
\text { group }\end{array}$} & \multicolumn{2}{|c|}{ Primnoisis antarctica } & \multicolumn{2}{|c|}{ Primnoella sp. } \\
\hline & $\mathrm{C}_{\text {control }}\left(\right.$ cells ml $\left.{ }^{-1}\right)$ & $\mathrm{C}_{\text {experiment }}\left(\right.$ cells ml $\mathrm{m}^{-1}$ ) & $\mathrm{C}_{\text {control }}$ (cells ml ${ }^{-1}$ ) & $\mathrm{C}_{\text {experiment }}\left(\right.$ cells ml $\left.\mathrm{ml}^{-1}\right)$ \\
\hline Bacteria & $1.25 \times 10^{5} \pm 0.31$ & $0.53 \times 10^{6} \pm 6.57$ & $2.28 \times 10^{6} \pm 0.61$ & $4.49 \times 10^{6} \pm 2.15$ \\
\hline Nanoflagellates & $202.48 \pm 103.79$ & $614.38 \pm 388.96$ & $265.16 \pm 79.77$ & $341.41 \pm 144.83$ \\
\hline Ciliates & $0.24 \pm 0.06$ & $0.18 \pm 0.05$ & $0.94 \pm 0.52$ & $0.42 \pm 0.20$ \\
\hline Dinoflagellates & $3.12 \pm 0.10$ & $2.86 \pm 0.76$ & $13.22 \pm 9.33$ & $9.83 \pm 7.89$ \\
\hline Nitzschia spp. & $0.54 \pm 0.10$ & $0.48 \pm 0.39$ & $13.22 \pm 9.33$ & $5.39 \pm 7.80$ \\
\hline Fragillariopsis spp. & $8.77 \pm 2.46$ & $6.19 \pm 2.60$ & $37.82 \pm 39.81$ & $31.16 \pm 24.95$ \\
\hline \multirow[t]{2}{*}{ Centric diatoms } & $0.45 \pm 0.09$ & $0.31 \pm 0.06$ & $0.43 \pm 0.31$ & $0.30 \pm 0.17$ \\
\hline & $\left(\mathrm{mg} \mathrm{C} \mathrm{ml}^{-1}\right)$ & $\left(\mathrm{mg} \mathrm{C} \mathrm{ml}^{-1}\right)$ & $\left(\mathrm{mg} \mathrm{C} \mathrm{ml}^{-1}\right)$ & $\left(\mathrm{mg} \mathrm{C} \mathrm{ml}^{-1}\right)$ \\
\hline POC & $0.06 \pm 0.04$ & $0.17 \pm 0.05$ & $0.14 \pm 0.05$ & $0.24 \pm 0.18$ \\
\hline DOC & $2.01 \times 10^{-6} \pm 1.55$ & $2.14 \times 10^{-6} \pm 1.28$ & $0.24 \pm 0.22$ & $0.24 \pm 0.23$ \\
\hline
\end{tabular}

highest ingestion rate was for dinoflagellates followed by ciliates and centric diatoms.

Total ingestion rates, taking into account all seston groups and food items, of Primnoisis antarctica and Primnoella sp. were the same order of magnitude

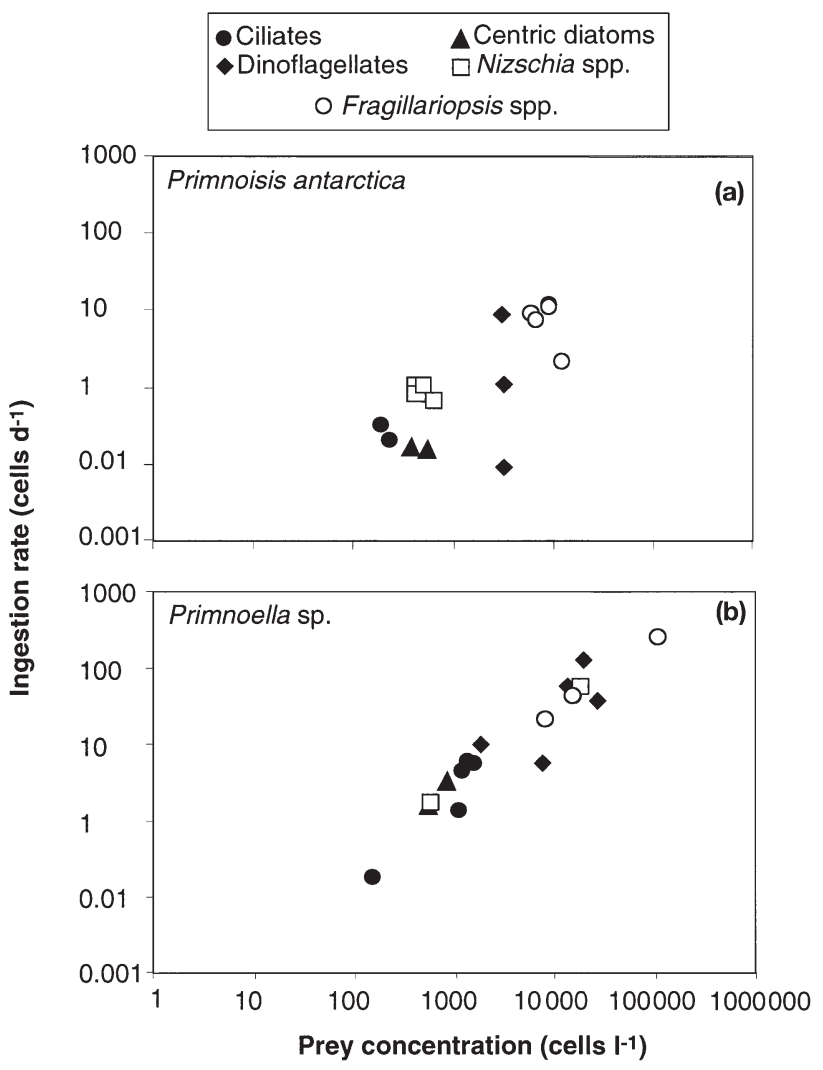

Fig. 5. Primnoisis antarctica and Primnoella sp. Ingestion rate $\left(\right.$ cells $\mathrm{d}^{-1}$ ) versus prey concentration (cells $\mathrm{l}^{-1}$ ) of (a) Primnoisis antarctica and (b) Primnoella sp. for each prey group. Logarithmic scale for both variables
(Table 3). However, Primnoella sp. generally exhibited higher ingestion rates than $P$. antarctica. Ingestion rates did not vary significantly due to different concentrations in P. antarctica (Fig. 5a), suggesting that the grazing on all groups was close to the maximum. In Primnoella sp. (Fig. 5b), there was a general tendency to increased predation when the cell concentration increased. A significant positive correlation between grazing rate and concentration in the environment was observed in 2 groups: ciliates $\left(\mathrm{r}^{2}=0.832 ; \mathrm{p}<0.05\right)$ and centric diatoms $\left(\mathrm{r}^{2}=0.891 ; \mathrm{p}<0.05\right)$. On average, $P$. antarctica and Primnoella sp. ingested $1.11 \times 10^{-5}$ $(\mathrm{SD} \pm 0.01) \mathrm{mg} \mathrm{C}$ polyp ${ }^{-1} \mathrm{~d}^{-1}$ and $1.34 \times 10^{-4}(\mathrm{SD} \pm 0.12)$ $\mathrm{mgC}$ polyp $\mathrm{p}^{-1} \mathrm{~d}^{-1}$, respectively, from these prey items (Table 3).

The available prey in the environment for both studied species is shown in Fig. 6. The composition of the plankton groups was quite similar in both cases, as would be expected because both samples were taken approximately from the same area and depth. The differences in the carbon content are caused by the cell size dependency of the carbon content (different cell sizes were found at the sampling stations).

The percentage contribution of each group to the diet of both species was also calculated (Fig. 7). For Primnoisis antarctica, Fragillariopsis spp. was the main contributor in terms of percentage of ingested cells $(77 \%)$, followed by dinoflagellates $(20 \%)$, Nitzschia spp. (2\%) and ciliates (1\%), whereas the higher contribution in mg C was supplied by Fragillariopsis spp. and dinoflagellates followed by ciliates and Nitzschia spp. In Primnoella sp., dinoflagellates accounted for $92 \%$ of ingested cells in the diet, followed by ciliates $(6 \%)$ and centric diatoms $(2 \%)$. The highest contribution in terms of $\mathrm{mgC}$ was made by dinoflagellates $(85 \%)$, followed by ciliates $(13 \%)$ and centric diatoms $(2 \%)$. 
Table 3. Primnoisis antarctica and Primnoella sp. Ingestion rates of each prey plankton group. Values are expressed as mean $( \pm \mathrm{SD})$ cells polyp ${ }^{-1} \mathrm{~d}^{-1}, \mathrm{mgC}$ polyp $\mathrm{d}^{-1}, \mathrm{mgC} \mathrm{mg} \mathrm{DM}^{-1} \mathrm{~h}^{-1}$ and $\mathrm{mgC} \mathrm{mg} \mathrm{AFDM}{ }^{-1} \mathrm{~h}^{-1}$

\begin{tabular}{|c|c|c|c|c|c|}
\hline Primnoisis antarctica & Ciliates & Dinoflagellates & Nitzschia spp. & Fragillariopsis spp. & Total \\
\hline Ingestion (cells polyp ${ }^{-1} \mathrm{~d}^{-1}$ ) & $0.12 \pm 1.66$ & $2.20 \times 10 \pm 4.64$ & $1.63 \times 10^{-1} \pm 1.64$ & $8.38 \times 10 \pm 3.87$ & $5.20 \times 10 \pm 0.45$ \\
\hline Ingestion (mg C polyp ${ }^{-1} \mathrm{~d}^{-1}$ ) & $3.53 \times 10^{-7} \pm 4.93$ & $9.99 \times 10^{-7} \pm 2.02$ & $6.22 \times 10^{-9} \pm 38$ & $1.13 \times 10^{-6} \pm 0.69$ & $1.11 \times 10^{-5} \pm 0.01$ \\
\hline Ingestion (mg C mg DM ${ }^{-1} \mathrm{~d}^{-1}$ ) & $3.97 \times 10^{-7} \pm 5.55$ & $1.12 \times 10^{-6} \pm 2.27$ & $6.99 \times 10^{-9} \pm 43$ & $1.27 \times 10^{-6} \pm 0.78$ & $1.25 \times 10^{-5} \pm 0.12$ \\
\hline Ingestion (mg C mg AFDM ${ }^{-1} \mathrm{~d}^{-1}$ ) & $4.21 \times 10^{-7} \pm 5.88$ & $1.19 \times 10^{-6} \pm 2.41$ & $7.41 \times 10^{-9} \pm 44.98$ & $1.34 \times 10^{-6} \pm 0.83$ & $1.32 \times 10^{-5} \pm 0.13$ \\
\hline Primnoella sp. & Ciliates & \multicolumn{2}{|c|}{ Dinoflagellates } & Centric diatoms & Total \\
\hline Ingestion (cells polyp ${ }^{-1} \mathrm{~d}^{-1}$ ) & $3.22 \times 10 \pm 3.11$ & \multicolumn{2}{|c|}{$4.87 \times 10^{1} \pm 5.18$} & $8.84 \times 10^{-1} \pm 1.80$ & $26.67 \times 10^{1} \pm 3.59$ \\
\hline Ingestion (mg C polyp ${ }^{-1} \mathrm{~d}^{-1}$ ) & $9.00 \times 10^{-6} \pm 0.10$ & \multicolumn{2}{|c|}{$1.58 \times 10^{-5} \pm 1.51$} & $1.92 \times 10^{-7} \pm 7.02$ & $1.34 \times 10^{-4} \pm 0.12$ \\
\hline Ingestion (mg C mg DM ${ }^{-1} \mathrm{~d}^{-1}$ ) & $1.41 \times 10^{-5} \pm 1.58$ & \multicolumn{2}{|c|}{$2.47 \times 10^{-5} \pm 2.36$} & $2.22 \times 10^{-7} \pm 12$ & $2.09 \times 10^{-4} \pm 0.19$ \\
\hline Ingestion $\left(\mathrm{mg} \mathrm{C} \mathrm{mg} \mathrm{AFDM}^{-1} \mathrm{~d}^{-1}\right)$ & $2.37 \times 10^{-5} \pm 2.66$ & \multicolumn{2}{|c|}{$4.16 \times 10^{-5} \pm 3.97$} & $3.74 \times 10^{-7} \pm 19$ & $3.52 \times 10^{-4} \pm 0.31$ \\
\hline
\end{tabular}

Nutrient concentrations were not significantly different at the beginning and at the end of the experiment. However, in some of the replicates the nitrite and nitrate concentrations were slightly higher at the end.

\section{DISCUSSION}

Predation on the small-planktonic communities by suspension feeders has recently been described in the literature. Studies of sponges in the Arctic (Pile et al. 1996), gorgonians in the Caribbean (Ribes et al. 1998b) as well as on several benthic Mediterranean species
(Ribes et al. 1999a,b) have shown high grazing efficiency by these benthic invertebrates on the smallplankton communities in near-bottom waters. In studies carried out on coral reefs in the Gulf of Aqaba (Red Sea), Yahel et al. (1998) showed that the taxa responsible for the depletion of phytoplankton at the reef were most likely species of sponges and ascidians. The results of this study are also consistent with previous gut contents studies (e.g. Lasker et al. 1983) as well as with feeding experiments carried out in the laboratory (Sorokin 1991). Thus, nano- and microplankton may constitute a regular feeding source for many gorgonian species. In general, anthozoans have a wide spectrum

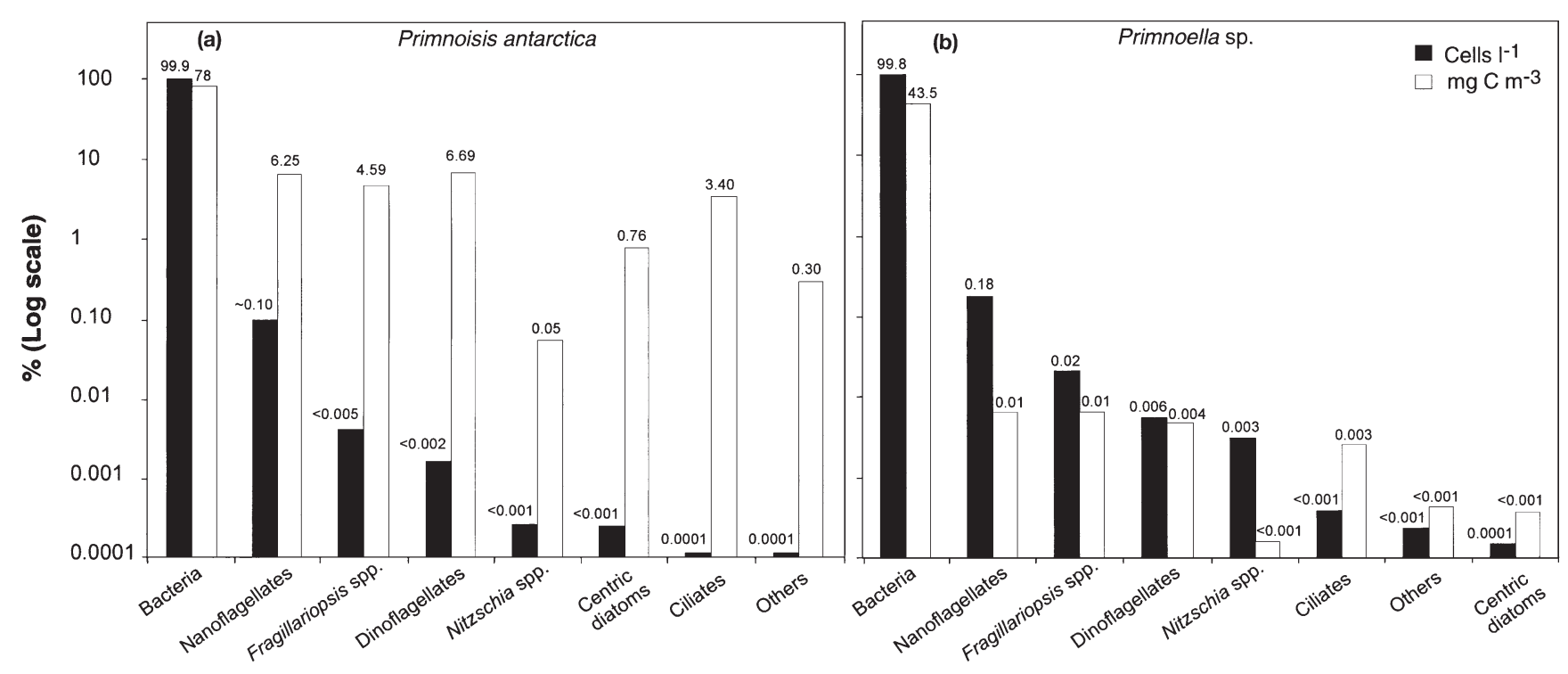

Plankton groups $(<100 \mu \mathrm{m})$ in the environment

Fig. 6. Primnoisis antarctica and Primnoella sp. Prey concentration split by each group in the respective environment where the gorgonians were sampled for (a) Primnoisis antarctica and (b) Primnoella sp. Black bars show prey concentration in \% of cells and white bars in \% of mg C (logarithmic scale) 

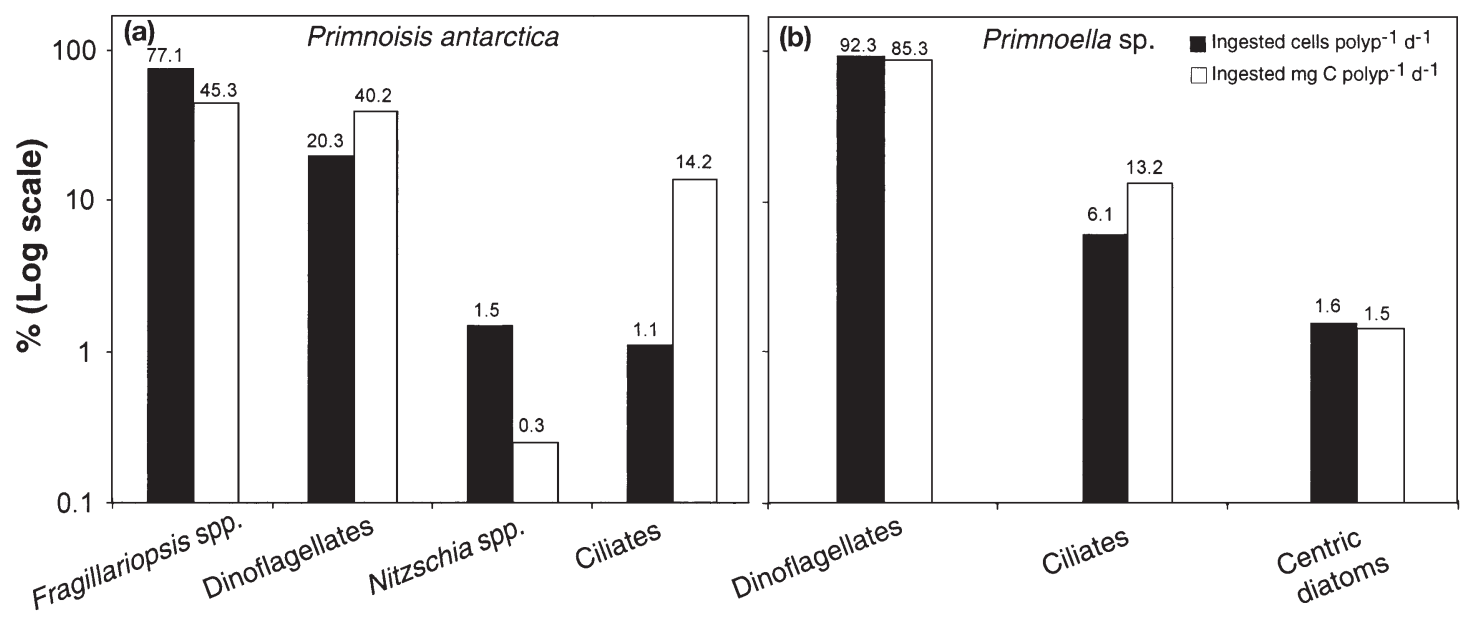

Fig. 7. Primnoisis antarctica and Primnoella sp. Ingested prey of each plankton group in \% for (a) Primnoisis antarctica and (b) Primnoella sp. Black bars show ingested prey in \% of cells and white bars in \% of mg C (logarithmic scale)

of potential prey including DOC and detrital and live POC (bacteria, protozoa, phytoplankton and zooplankton). Although in some species from other groups, a single prey type can provide most of the energy requirements (Asmus \& Asmus 1991), it appears that a wide and heterogeneous diet is a common feeding strategy in littoral benthic suspension feeders (e.g. Stuart \& Klumpp 1984, Coma et al. 2001). The fact that the Antarctic gorgonians studied here are able to predate on the fraction of seston $>5 \mu \mathrm{m}$ corroborates this general trend in sessile suspension feeders. The Antarctic hydrozoan Oswaldella antarctica also feeds on the small plankton (Orejas et al. 2001), although hydroids have traditionally been considered as carnivorous (Gili \& Hughes 1995). All these observations demonstrate that bacteria, phytoplankton and suspended organic matter may play an extremely important role in the feeding of non-molluscan suspension feeders (e.g. Riisgård 1991, Coma et al. 2001). Other Antarctic species also show this trend, including some ascidians feeding mainly on particles between 1.2 and $6.5 \mu \mathrm{m}$ (Kowalke 1999) and the bivalve Laternula elliptica (Ahn 1993), which filters $<5 \mu \mathrm{m}$ particles similar to bivalves in other latitudes (Jørgensen 1990).

Feeding studies on gorgonians have only rarely reported the capture of zooplankton prey items (e.g. Lasker et al. 1983). For this reason, alternative food sources have been proposed (Murdock 1978, Lasker 1981, Coffroth 1984, Herndl \& Velimirov 1986, Pile et al. 1996, Ribes et al. 1999a). Significant capture of naturally occurring zooplankton prey close to the bottom has only been documented in the Mediterranean species Paramuricea clavata (Coma et al. 1994) and the Caribbean gorgonians Plexaura flexuosa and Pseudo- plexaura porosa (Ribes et al. 1998b). In the Antarctic species studied, Primnoisis antarctica specimens had a very small amount of zooplankton prey items in their gastrovascular cavities. However, as in P. clavata (Coma et al. 1994), the small contribution of zooplankton prey might be very important to cover the energy requirements of the species, since the carbon ingested via zooplankton prey items represents a larger contribution to energy balance than that of micro-, nanoand picoplankton items. The combination of low metabolism (Clarke 1998) and individual nutritive prey could compensate for a long period of limited food availability. Specimens of Primnoella sp. did not show any zooplankton prey items in their gastrovascular cavities. We observed, however, that all dissected polyps were filled by well-developed gonads (up to 13 oocytes in 1 gastrovascular cavity) which might explain the absence of large prey. This same phenomenon has been mentioned by Brito et al. (1997) for the Antarctic gorgonian Thouarella variabilis.

The observation of finding few large prey in the gastric cavity of only 1 of the 2 species studied might be connected with a low abundance of these prey in the gorgonian habitat, or due to sampling constraints resulting in the collection of colonies without food remains. The importance of zooplankton prey for sessile passive suspension feeders remains an open question (see Gili et al. 2001).

On average, a colony of Primnoisis antarctica (biomass: $1.91 \mathrm{~g}$ AFDM) ingested $1.32 \times 10^{-5} \pm 0.13 \mathrm{mgC}$ $\mathrm{mg} \mathrm{AFDM}^{-1} \mathrm{~d}^{-1}$ of particles $<100 \mu \mathrm{m}$, comprising ciliates, flagellates and phytoplankton. If we consider the respiration rate of $P$. antarctica as $0.007 \mathrm{ml} \mathrm{O}_{2} \mathrm{~h}^{-1}$ colony $^{-1}$ (Gili et al. 1999), which in terms of energy 
Table 4. Comparative concentration values $\left(\times 10^{3} \mathrm{cells} \mathrm{ml}^{-1}\right)$ of the different groups which constitute the small fraction of seston in different seas at different latitudes. -: no data available

\begin{tabular}{|c|c|c|c|c|c|c|}
\hline Location & $\begin{array}{l}\text { Depth } \\
(\mathrm{m})\end{array}$ & $\begin{array}{l}\text { Pico- } \\
\text { plankton }\end{array}$ & $\begin{array}{c}\text { Pico- } \\
\text { eucaryotes }\end{array}$ & $\begin{array}{c}\text { Autotrophic } \\
\text { nanoeucaryotes }\end{array}$ & $\begin{array}{c}\text { Heterotrophic } \\
\text { nanoeucaryotes }\end{array}$ & Source \\
\hline Baltic Sea & $10-20$ & $30-80$ & - & - & - & Larsson \& Hangström (1982) \\
\hline Celtic Sea & $0-50$ & $200-600$ & - & - & $<1-7$ & Joint \& Pomroy (1983) \\
\hline $\begin{array}{l}\text { Gulf Stream } \\
\text { (Slope Water/North) }\end{array}$ & - & \pm 1 & - & - & - & Waterbury et al. (1979) \\
\hline Woods Hole Harbor & - & $2-360$ & - & - & - & Waterbury et al. (1979) \\
\hline $\begin{array}{l}\text { Nova Scotia, coastal } \\
\text { slope and eddy }\end{array}$ & $\sim 200$ & $4-50$ & - & - & - & Douglas (1984) \\
\hline Rhode Island shelf & $50-100$ & 495 & - & - & - & Johnson \& Sieburth (1979) \\
\hline Narragansett Bay & $50-100$ & 1800 & - & - & - & Johnson \& Sieburth (1979) \\
\hline Japan, coastal waters & $0-70$ & $<1-100$ & - & - & - & Takahashi et al. (1985) \\
\hline Mediterranean Sea & 15 & 516 & 1.64 & $<1$ & $<1$ & Ribes et al. (1998a) \\
\hline Azores & $65-89$ & $4-17$ & - & - & - & Platt et al. (1983) \\
\hline Red Sea (Aqaba Gulf) & $1-50$ & - & $<1-8$ & - & - & Yahel et al. (1998) \\
\hline Costa Rica Dome & $0-80$ & $500-1500$ & - & - & - & Li et al. (1983) \\
\hline Peru and Arabian Sea & $200-400$ & $<0.01-0.3$ & - & - & - & Waterbury et al. (1979) \\
\hline Hawaii & $0-30$ & 690 & - & $<1$ & \pm 1 & Laws et al. (1984) \\
\hline Signy Island (Antarctica) & $20-25$ & 304 & - & - & - & Clarke \& Leakey (1996) \\
\hline Weddell Sea & $250-300$ & $117-252$ & $<1$ & - & $<1$ & This study \\
\hline
\end{tabular}

equivalents should be approximately $0.338 \mathrm{cal} \mathrm{mg}$ $\mathrm{AFDM}^{-1} \mathrm{~d}^{-1}$, the small-plankton communities should cover approximately $49 \%$ of the daily energy demand. These results are consistent with previous gut content studies in other areas (e.g. Coma et al. 2002) and show the relevance of the small food fraction in Antarctic anthozoans. This study constitutes a first approach for the evaluation of the grazing impact of sessile passive suspension feeders on pico- and nanoplankton communities in the Southern Ocean, and our results suggest that they make an important grazing impact. However, further effort on the study of other species under natural conditions and at different periods of the year is necessary to obtain an accurate estimate of the grazing impact of these organisms.

The Antarctic octocorals studied seem to show the same trophic behaviour as octocorals studied in other latitudes, i.e. not making much use of large zooplankters but feeding primarily on the small-plankton communities, which is the most available food everywhere (Table 4) (see for example Stoeckner \& Antia 1986, Burkill et al. 1993). The observed grazing on benthic diatoms in the feeding experiments leads to the conclusion that resuspension may play an important role in the food available for these organisms. Sedimented fresh material, such as phytoplankton, represents a primary food source for temperate gorgonians (Rossi 2002) and other sessile organisms including active filter feeders (Riisgård \& Kamermans 2001). Sediment resuspension is a common phenomenon already documented in shallow nearshore environments surrounding Antarctica (e.g. Klöser et al. 1994). This phenome- non may be particularly relevant during the austral winter. In shallow areas, detritus resuspended by wind-generated waves, anchor ice and currents may be a viable food source for benthic invertebrates during this season. This phenomenon has been called the 'utilisation of redistributed accumulated energy' (Gruzov 1977).

The apparent difference with regard to species studied in other latitudes does not refer to the quality but to the quantity of food Antarctic octocorals ingest, which is significantly lower. As mentioned above, Antarctic organisms have low metabolic rates (Clarke 1991), which suggests higher growth efficiencies and reduced cost of maintenance. In addition, low resting metabolic rates provide energy advantages (overwintering reserves can be reduced) but limit the rate at which food can be processed because of this energetic constraint. However, the Antarctic octocorals might be able to feed during the whole year, whereas octocorals from temperate seas have a seasonal feeding behaviour. This seasonality may be due to the fact that suspension feeders grow mainly on hard bottoms in temperate regions where resuspended material is not available to the same extent as in Antarctic waters. Other octocorallian species, such as some pennatulaceans, develop dense populations in deeper soft bottoms (Langton et al. 1990) where resuspension and small prey could be the main food sources, as in the Antarctic benthic communities.

Similar to the 2 gorgonians studied, several Antarctic bryozoans are also adapted to feed at very low cell concentrations, indicating that the polar winter may be 
shorter and less harsh for shallow-water benthic suspension feeders than previously thought (Barnes \& Clarke 1994). One of these bryozoan species, Arachnopusia inchoata, continued feeding all year and 3 others showed only relatively short periods of winter cessation of feeding activity. The feeding behaviour of the bryozoans studied by Barnes \& Clarke (1994) could explain the absence of over-wintering energy reserves in these benthic suspension feeders (Peck et al. 1986, 1987), related to reduced metabolic costs in benthos compared with plankton (Clarke \& Peck 1991). The work of Barnes \& Clarke (1994) was one of the first studies which challenged the concept of the long winter period as a 'hibernation' time in polar sessile suspension feeders (Gruzov 1977), i.e. the idea of a long winter period of starvation, which was a dominant concept in Antarctic marine ecology for many years (Clarke 1988).

Acknowledgements. Financial support was provided by a DAAD (Deutscher Akademischer Austauschdienst) fellowship (A/96/13073), by a European Commission fellowship under the programme 'Training and Mobility of Researchers' (TMRCT97-2813) and by CICYT (Spanish Antarctic Research Program) grants (ANT97-1533-E, ANT98-1739-E and ANT0991608-E). We especially thank N. Teixidó and K. Beyer for help in the laboratory. J. M. Gasol assisted with flow cytometry. Thanks also to E. Nöthig who helped with the phytoplankton identification and $\mathrm{H}$. Schwarz for laboratory assistance. Thanks go to T. Brey, A. Clarke, I. Gomez, F. Pagès, M. Ribes and S. Schiel, whose comments very much improved the manuscript. Thanks also to the Scientists' Technical Service (University of Barcelona) who provided the POC and DOC analyses. The authors are grateful to many colleagues who helped on board, and to officers and crew of RV 'Polarstern' for their co-operation and hospitality during the EASIZ II cruise.

\section{LITERATURE CITED}

Ahn I (1993) Enhanced particle flux through the biodeposition by the Antarctic suspension-feeding bivalve Laternula elliptica in Marian Cove, King George Island. J Exp Mar Biol Ecol 171:75-90

Albertelli G, Cattaneo-Vietti R, Chiantore M, Pusceddu A, Fabiano M (1998) Food availability to an Adamussium bed during the austral summer 1993/1994 (Terra Nova Bay, Ross Sea). J Mar Syst 17:425-434

Alvà V, Orejas C, Zabala M (1997) Feeding ecology of Antarctic cnidarian suspension feeders (Hydrozoa, Gorgonacea, Pennatulacea). In: Arntz W, Gutt J (eds) The expedition Antarktis XIII/3 (EASIZ I) of 'Polarstern' to the eastern Weddell Sea in 1996. Ber Polarforsch 249:14-16

Arntz WE, Gutt J (1999) The expedition Antarktis XV/3 (EASIZ II) of RV 'Polarstern' in 1998. Ber Polarforsch 301

Arntz WE, Brey T, Gallardo VA (1994) Antarctic zoobenthos. Oceanogr Mar Biol Annu Rev 32:241-304

Asmus RM, Asmus H (1991) Mussel beds: limiting or promoting phytoplankton? J Exp Mar Biol Ecol 148:215-232

Azam FT, Fenchel JG, Field JS, Gray LA, Meyer-Reil LA, Thingstand F (1983) The ecological role of water-column microbes in the sea. Mar Ecol Prog Ser 10:257-263
Barnes DKA, Clarke A (1994) Seasonal variation in the feeding activity of 4 species of Antarctic bryozoa in relation to environmental factors. J Exp Mar Biol Ecol 181:117-133

Barnes DKA, Clarke A (1995) Seasonality of feeding activity in Antarctic suspension feeders. Polar Biol 15:335-340

Brito TAS, Tyler PA, Clarke A (1997) Reproductive biology of the Antarctic octocoral Thouarella variabilis Wright and Studer 1889. Proc 6th Int Conf Coelenterate Biol 1995. Natural History Museum, Leiden, p 63-69

Burkill PH, Mantoura RFC, Owens NJP (1993) Biogeochemical cycling in the northwestern Indian Ocean: a brief overview. Deep-Sea Res II 40:643-649

Clarke A (1988) Seasonality in the Antarctic marine environment. Comp Biochem Physiol 90B(3):461-473

Clarke A (1991) What is cold adaptation and how should we measure it? Am Zool 31:81-92

Clarke A (1998) Temperature and strategies: an introduction to cold ocean physiology. In: Pörtner HO, Playle RC (eds) Cold ocean physiology. Cambridge University Press, Cambridge, p 3-30

Clarke A, Leakey RJG (1996) The seasonal cycle of phytoplankton, macronutrients, and the microbial community in a nearshore Antarctic marine ecosystem. Limnol Oceanogr 41(6):1281-1294

Clarke A, Peck L (1991) The physiology of polar marine zooplankton. Polar Res 10:355-369

Coffroth MA (1984) Ingestion and incorporation of coral mucus aggregates by a gorgonian soft coral. Mar Ecol Prog Ser 17:193-199

Coma R, Gili JM, Zabala M, Riera T (1994) Feeding and prey capture cycles in the aposymbiotic gorgonian Paramuricea clavata. Mar Ecol Prog Ser 115:257-270

Coma R, Ribes M, Zabala M, Gili JM (1995) Reproduction and cycle of gonadal development in the Mediterranean gorgonian Paramuricea clavata. Mar Ecol Prog Ser 117: $173-183$

Coma R, Ribes M, Gili JM, Hughes RN (2001) The ultimate opportunist: consumers of seston. Mar Ecol Prog Ser 219: 305-308

Coma R, Ribes M, Gili JM, Zabala M (2002) Seasonal variation of respiration rate in situ in three temperate benthic suspension feeders. Limnol Oceanogr 47:324-331

Davenport J (1997) Comparisons of the biology of the intertidal subantarctic limpets Nacella concinna and Kerguelnella lateralis. J Molluscan Stud 63(1):39-48

Douglas DJ (1984) Microautoradiography-based enumeration of photo-synthetic picoplankton with estimates of carbon specific growth rates. Mar Ecol Prog Ser 14:223-228

Edler L (1979) Recommendations on methods for marine biological studies in the Baltic Sea. Phytoplankton and chlorophyll. Baltic Mar Biol Publ 5:1-38

Fabricius KE, Benayahu Y, Genin A (1995) Herbivory in asymbiotic soft corals. Science 268:90-92

Fry JC (1988) Determination of biomass. In: Austin B (ed) Methods in aquatic bacteriology. Wiley-Liss, New York, p 27-72

Galéron J, Herman RL, Arnaud PM, Arntz WE, Hain S, Klages M (1992) Macrofaunal communities on the continental shelf and slope of the southeastern Weddell Sea, Antarctica. Polar Biol 12:283-290

Gasol JM, del Giorgio P (2000) Using flow cytometry for counting natural planktonic bacteria and understanding the structure of planktonic bacterial communities. Sci Mar 64:197-224

Gili JM, Coma R (1998) Benthic suspension feeders: their paramount role in littoral marine food webs. Trends Ecol Evol 13:316-321 
Gili JM, Hughes RG (1995) Ecology of benthic hydroids. Oceanogr Mar Biol Annu Rev 33:351-422

Gili JM, Arntz WE, Filipe P, López P, Orejas C, Ros J, Teixidó $N$ (1999) The role of benthic suspension feeders in Antarctic communities. In: Arntz WE, Gutt J (eds) The expedition Antarktis XV/3 (EASIZ III) of RV 'Polarstern' in 1998. Ber Polarforsch 301:30-83

Gili JM, Coma R, Orejas C, López-González PJ, Zabala M (2001) Are Antarctic suspension-feeding communities different from those elsewhere in the world? Polar Biol 24: 473-485

Grasshoff K (1976) Methods of seawater analysis. Verlag Chemie, Weinheim

Gruzov EN (1977) Seasonal alterations in coastal communities in the Davis Sea. In: Llano GA (ed) Adaptations within Antarctic ecosystems. Smithsonian Institution Press, Washington, p 263-278

Gutt J, Starmans A (1998) Structure and biodiversity of megabenthos in the Weddell and Lazarev Seas (Antarctic): ecological role of physical parameters and biological interactions. Polar Biol 20:229-247

Herndl GJ, Velimirov B (1986) Microheterotrophic utilisation of mucus released by the Mediterranean coral Cladocora cespitosa. Mar Biol 90:363-369

Hewes GA, Holm-Hansen O, Sakshaug E (1985) Alternate carbon pathways at lower trophic levels in the Antarctic food web. In: Siegfried WR, Condy P, Laws RM (eds) Antarctic nutrient cycles and food webs. Springer-Verlag, Berlin, p 277-283

Johnson PW, Sieburth JMcN (1979) Chrococcoid cyanobacteria in the sea: a ubiquitous and diverse phototrophic biomass. Limnol Oceanogr 24:928-935

Joint IR, Pomroy AJ (1983) Production of picoplankton and small nanoplankton in the Celtic Sea. Mar Biol 77:19-27

Jørgensen CB (1990) Bivalve filter feeding: hydrodynamics, bioenergetics, physiology and ecology. Olsen \& Olsen, Fredensborg

Klöser H, Ferreyra G, Schloss I, Mercuri G, Laturnus F, Curtosi A (1994) Hydrography of Potter Cove, a small, fjordlike inlet on King George Island (South Shetlands). Estuar Coast Shelf Sci 38:523-537

Kowalke J (1999) Filtration in Antarctic ascidians - striking a balance. J Exp Mar Biol Ecol 242:233-244

Kowalke J (2000) Ecology and energetics of two Antarctic sponges. J Exp Mar Biol Ecol 247:85-97

Langton RW, Langton EW, Theroux RB, Uzmann JR (1990) Distribution, behavior and abundance of sea pens, Pennatula aculeata, in the Gulf of Maine. Mar Biol 107:463-469

Larsson U, Hagström Å (1982) Fractioned phytoplankton primary production, exudate release and bacterial production in a Baltic eutrophication gradient. Mar Biol 67:57-70

Lasker HR (1981) A comparison of the particulate feeding abilities of three species of gorgonian soft coral. Mar Ecol Prog Ser 5:61-67

Lasker HR, Gottfried MD, Coffroth MA (1983) Effects of depth on the feeding capabilities of two octocorals. Mar Biol 73: $73-78$

Laws EA, Redalje DG, Haas LW, Bienfang PK, Eppley RW, Harrison WG, Karl DM, Marra J (1984) High phytoplankton growth and production rates in oligotrophic Hawaiian coastal waters. Limnol Oceanogr 29(6):1161-1169

Lewis JB (1982) Feeding behaviour and feeding ecology of the Octocorallia (Coelenterata: Anthozoa). J Zool Lond 196:371-384

Li WKW, Subba Rao DV, Harrison WG, Smith JC, Cullen JJ, Irwin B, Platt T (1983) Autotrophic picoplankton in the tropical ocean. Science 219:292-295
Loya Y (1972) Community structure and species diversity of hermatypic corals at Eilat, Red Sea. Mar Biol 13:100-123

Murdock GR (1978) Digestion, assimilation, and transport of food in the gastrovascular cavity of a gorgonian octocoral (Cnidaria, Anthozoa). Bull Mar Sci 28:354-362

Nöthig EM, von Bodungen B, Sui Q (1991) Phyto- and protozooplankton biomass during austral summer in surface waters of the Weddell Sea and vicinity. Polar Biol 11: 293-304

Officer CB, Smayda TJ, Mann R (1982) Benthic filter feeding: a natural eutrophication control. Mar Ecol Prog Ser 9:203-210

Orejas C, Gili JM, López-González PJ, Arntz WE (2001) Feeding strategies and diet composition of four Antarctic cnidarian species. Polar Biol 24:620-627

Orejas C, López-González PJ, Gili JM, Teixidó N, Gutt J, Arntz WE (2002) Distribution and reproductive ecology of the Antarctic octocoral Ainigmaptilon antarcticum in the Weddell Sea. Mar Ecol Prog Ser 231:101-114

Peck LS, Morris DJ, Clarke A, Holmes LJ (1986) Oxygen consumption and nitrogen excretion in the Antarctic brachiopod Liothyrella uva (Kackson, 1912) under simulated winter conditions. J Exp Mar Biol Ecol 104:203-213

Peck L, Clarke A, Holmes L (1987) Size, shape and the distribution of organic matter in the recent Antarctic brachiopod Liothyrella uva. Lethaia 20(1):33-40

Pile A, Patterson MR, Witman JD (1996) In situ grazing on plankton $<10 \mu \mathrm{m}$ by the boreal sponge Mycale lingua. Mar Ecol Prog Ser 141:95-102

Platt T, Subba Rao DV, Irwin B (1983) Photosynthesis of picoplankton in the oligotrophic ocean. Nature 301:702-704

Porter KG, Feig YS (1980) The use of DAPI for identifying and counting aquatic microflora. Limnol Oceanogr 25:943-948

Ribes M, Coma R, Gili JM (1998a) Seasonal variation of in situ feeding rates by the temperate ascidian Halocynthia papillosa. Mar Ecol Prog Ser 175:201-213

Ribes M, Coma R, Gili JM (1998b) Heterotrophic feeding by gorgonian corals with symbiotic zooxanthella. Limnol Oceanogr 43(6):1170-1179

Ribes M, Coma R, Gili JM (1999a) Heterogeneous feeding in benthic suspension feeders: the natural diet and grazing rate of the temperate gorgonian Paramuricea clavata (Cnidaria: Octocorallia) over a year cycle. Mar Ecol Prog Ser 183:125-137

Ribes M, Coma R, Gili JM (1999b) Natural diet and grazing rate of the temperate sponge Dysydea avara (Demospongiae, Dendroceratida) throughout an annual cycle. Mar Ecol Prog Ser 176:179-190

Ribes M, Coma R, Gili JM, Svoboda A, Julia A, Parera J (2000) An improved 'semi-closed' recirculating system for the in situ study of feeding and respiration of benthic suspension feeders. Sci Mar 64:265-275

Riisgård HU (1991) Suspension feeding in the polychaete Nereis diversicolor. Mar Ecol Prog Ser 70:29-37

Riisgård HU, Kamermans P (2001) Switching between deposit and suspension feeding in coastal zoobenthos. In: Reise K (ed) Ecological comparisons of sedimentary shores. Ecol Stud 115:73-101

Riisgård HU, Larsen PS (2001) Comparative ecophysiology of active zoobenthic filter-feeding, essence of current knowledge. J Sea Res 44:169-193

Riisgård HU, Jensen AS, Jürgensen C (1998) Hydrography, near-bottom currents, and grazing impact of the filterfeeding ascidian Ciona intestinalis in a Danish fjord. Ophelia 49(1):1-16

Rossi S (2002) Environmental factors affecting the trophic ecology of benthic suspension feeders. PhD thesis, University of Barcelona 
Sahade R, Tatián M, Kowalke J, Kühne S, Esnal GB (1998) Benthic faunal associations on soft substrates at Potter Cove, King George Island, Antarctica. Polar Biol 19:85-91

Saiz E (1993) Sources of variability in zooplankton feeding experiments: the importance of accurate determination of algal growth rates. Sci Mar 57:23-29

Sakshaug E, Holm-Hansen O (1984) Factors governing pelagic production in polar oceans. In: Holm-Hansen $\mathrm{O}$, Bolis L, Gilles R (eds) Marine phytoplankton and productivity. Lecture Notes on Coastal and Estuarine Studies, Vol. 8. Springer-Verlag, Berlin, p 1-18

Sanderson WG, Thorpe JP, Clarke A (1994) A preliminary study of feeding rates in the Antarctic cheilostome bryozoan Himantozoum antarcticum. In: Hayward PJ, Ryland JS, Taylor PD (eds) Biology and paleobiology of Bryozoans. Olsen \& Olsen, Fredensborg, p 167-170

Scharek R, Nöthig E (1995) Das einzellige Plankton im Ozean der Arktis und Antarktis. In: Hempel I, Hempel G (eds) Biologie der Polarmeere. Gustav Fischer Verlag, Jena, p 116-127

Sebens KP, Vandersall KS, Savina LA, Graham KR (1996) Zooplankton capture by two scleractinian corals, Madracis mirabilis and Monastrea cavernosa, in a field enclosure. Mar Biol 127:303-317

Sokal RR, Rohlf FJ (1995) Biometry. WH Freeman and Co, San Francisco

Sorokin YI (1991) Biomass, metabolic rates and feeding of some common reef zoantharians and octocorals. Aust J Mar Freshw Res 42:729-741

Starmans A, Gutt J, Arntz WE (1999) Mega-epibenthic com-

Editorial responsibility: Otto Kinne (Editor),

Oldendorf/Luhe, Germany munities in Arctic and Antarctic shelf areas. Mar Biol 135: 269-280

Stoeckner JG, Antia NJ (1986) Algal picoplankton from marine and freshwater ecosystems: a multidisciplinary perspective. Can J Fish Aquat Sci 43:2472-2503

Stuart V, Klump DW (1984) Evidence for food-resource partitioning by kelp-bed filter feeders. Mar Ecol Prog Ser 16: $27-37$

Takahashi M, Kikuchi K, Hara Y (1985) Importance of picocyanobacteria biomass (unicellular, blue-green algae) in the phytoplankton population of the coastal waters off Japan. Mar Biol 89:63-69

True MA (1970) Étude quantitative de quatre peuplements sciaphiles sur substrat rocheux dans la région Marseilles. Bull Inst Oceanogr 1410:1-48

Utermöhl H (1931) Neue Wege in der quantitativen Erfassung des Planktons (Mit besonderer Berücksichtigung des Ultraplanktons). Verh Int Ver Theor Angew Limnol 5:567-596

Utermöhl L (1958) Zur Vervollkommnung der quantitativen Phytoplankton-Methodik. Mitt Int Ver Theor Angew Limnol 9:1-38

Voß J (1988) Zoogeographie und Gemeinschaftsanalyse des Makrozoobenthos des Weddellmeeres (Antarktis). Ber Polarforsch 45:1-145

Waterbury JB, Watson SW, Guillard RRW, Brand LE (1979) Widespread occurrence of an unicellular marine planktonic cyanobacterium. Nature 277:293-294

Yahel G, Post AF, Fabricius K, Vaulot DM, Vaulot D, Genin A (1998) Phytoplankton distribution and grazing near coral reefs. Limnol Oceanogr 43(4):551-563

Submitted: June 5, 2001; Accepted: October 22, 2002

Proofs received from author(s): February 28, 2003 